\title{
Formation of Asperites on the Plate-like Alumina Particles by Molten-salt Method
}

\author{
Yoon Joo Lee, Bo Yeon Kim, Dong-geun Shin, Soo Ryong Kim, Woo Teck Kwon, and Younghee Kim ${ }^{\dagger}$ \\ Energy Efficient Material Team, Korea Institute of Ceramic Engineering and Technology, Seoul 153-801, Korea \\ (Received November 24, 2014; Accepted November 27, 2014)
}

\section{Molten-salt 방법에 의해 합성되는 판상형 알루미나 분말 표면에 돌기형성 거동

\author{
이윤주 · 김보연 · 신동근 · 김수룡 · 권우택 · 김영희 ${ }^{\dagger}$ \\ 한국세라믹기술원 에너지효율소재팀
} \\ (2014년 11월 24일 접수 ; 2014년 11월 27일 채택)}

\begin{abstract}
Alumina nano-asperites were grown on plate-like alumina particles of which the surface had been covered with a capping agent to control the asperite formation sites on the particles. Utilized alumina source for asperite was nano sized $\gamma$-alumina, which was prepared by calcination of $\mathrm{Al}(\mathrm{OH})_{3}$ at $600^{\circ} \mathrm{C}$; silica suspension was used as the capping agent. Plate like alumina particles were covered by silica suspension and continuously heat-treated to $900^{\circ} \mathrm{C}$ with nano sized $\gamma$-alumina, as the source material, under molten-salt atmosphere. Asperite growing site were controlled by the degree of coating of the capping agent; 10-20 nanosize of $\theta$-alumina were formed on the particle surface. On the other hand, alumina particles without capping agent were observed to undergo only step-like crystal growth during heat-treatment.
\end{abstract}

Key words : Asperite, Crystal growth, Alumina, Capping agent, Molten-salt

\section{1. 서 론}

기술의 발달과 더불어 고기능성 소재 혹은 새로운 기능 을 나타내는 신소재에 대한 관심이 커지고 있다. 대표적인 움직임이 자연으로부터 새로운 현상이나 또는 획기적인 기 능의 신소재를 설계하는 것으로 이를 전산모사 또는 자연 모방 기술이라고 하며, 연잎(lotus leaf), 거미줄(spider silk)의 발수 기능, 개코(Gecko) 도마뱀 발의 접착성, 전복껍질 (abalone shell)이 나타내는 고강도 특성 등을 모방하고자 하 는 연구들이 대표적인 예라고 할 수 있다. ${ }^{1-3)}$ 그 중에서도 전복껍질은 $95 \%$ 이상이 탄산칼슘으로 이루어져 있는데, 박 형의 구조체임에도 불구하고 이론값에 비하여 높은 기계적 강도와 파괴인성을 나타내고 있어 대표적인 경량 복합소재 의 모방소재로 관심이 높다.-6) 이에 전복껍질의 고강도 발 현 특성을 구조적인 측면에서 이해하기 위하여, 전복껍질 의 구조와 함께 기계적 특성을 해석한 연구가 다수 보고 되고 있다. 전복껍질은 아라고나이트상의 판상형 탄산칼 슘 타블렛이 일정한 배열로 적층되어 있고 그 사이를 생

\footnotetext{
${ }^{\dagger}$ Corresponding author : Younghee Kim

E-mail : yhkokim@kicet.re.kr

Tel : +82-2-3282-2472 Fax : +82-2-3282-2430
}

체고분자가 잡아주고 있는 "brick \& mortar" 구조를 가지 고 있는데, 전복껍질의 파괴 거동은 탄산칼슘 타블렛의 pullout에 현상에 기인하고 있음이 알려져 있다. 무엇보다 탄산칼슘 타블렛의 표면에는 나노 크기의 수많은 돌기 (asperite)가 형성되어 있어 탄산칼슘 타블렛이 pullout될 때 돌기들에 의한 앵커링(anchoring) 효과로 인하여 전단 응력이 향상된다. ${ }^{7-9)}$

알루미나는 뛰어난 기계적 강도와 높은 내마모성, 내열 성에 기인하여 내마모재, 촉매담체, 필터 등 사용범위가 광범위하다. 이로 인해 원료로 사용되고 있는 알루미나 분말의 산업적 이용범위도 다양해지고 있는데, 특히 판상 형 알루미나 입자의 경우 코스메틱, 페인트, 플라스틱 등 의 안료 혹은 필러로 사용되어 심미적 효과를 부여하는 용도로도 개발되고 있다. ${ }^{10-12)}$ 뿐만 아니라 판상형 알루미 나를 균일하게 배향하여 전복껍질 구조를 모방한 복합체 제조에 대한 연구가 이루어지고 있다. ${ }^{13-15)}$ 이때 알루미나 입자의 배향기술과 더불어 입자 표면에 나노돌기 구조를 형성하는 기술이 매우 중요한데, 아직 이에 대한 연구결 과는 보고되지 않았다.

결정의 성장은 결정면에 따라 그 성장 속도가 다르기 때문에 계면의 성장 속도를 조절함으로써 다양한 입자 설 계가 가능하다. 결정성 세라믹 입자의 경우 molten-salt, 수 
Table 1. Summaries of the Synthesis Condition by Molten-salt Method

\begin{tabular}{cccccc}
\hline Condition & Sample Name & Alumina Flake & $\gamma$-alumina & Silica & Salt $(\mathrm{NaCl}+\mathrm{KCl})$ \\
\hline$\gamma$-alumina with silica & BL1 & 10 & 2.5 & 1 & 30 \\
$\gamma$-alumina only & BO & 10 & 3 & - & 30 \\
silica only & LU & 10 & - & 3 & - \\
\hline
\end{tabular}

열합성법으로 제조시 반응 온도, 시간 혹은 $\mathrm{pH}$ 를 조절함 으로써 다면체, 판상형, $\operatorname{rod}$ 형태의 결정을 얻을 수 있는 데, ${ }^{16-18)}$ 최근에는 capping agent를 이용하여 보다 다양한 형태의 입자 설계가 가능해졌다. ${ }^{19,20)}$ 알루미나 역시 moltensalt 방법, 수열합성법 등으로 제조가 가능한데, ${ }^{21-23)}$ 그 중 에서도 molten-salt 방법이란 용융 온도가 낮은 salt를 이 용하여 세라믹 입자의 결정을 성장시키는 방법으로, salt 의 ionic strength 차이에 의하여 세라믹 입자의 성장시 결 정면의 성장 속도를 조절할 수 있다. 기존 연구에 의하면 $\mathrm{NaCl}, \mathrm{KCl}, \mathrm{Na}_{3} \mathrm{PO}_{4}, \mathrm{Na}_{2} \mathrm{SO}_{4}$ 를 salt로 이용하였을 경우 판 상형 알루미나가 형성되는데, ${ }^{24,25)}$ 이 때 각 이온의 ionic strength에 따라 판상입자의 종횡비 조절이 가능하였다. ${ }^{26)}$

본 연구에서는 molten-salt 방법을 이용하여 판상형 알 루미나 입자 표면에 동종(iso-crystallographic)의 알루미나 나노돌기를 형성하고자 하였으며, 이때 입자 표면에 capping agent를 도포하여 핵생성 사이트를 조절하고자 하였다. 일 반적으로 capping agent는 유기물 소재가 쓰이고 있는데, $800^{\circ} \mathrm{C}$ 에서 용융되는 salt 조건에서는 유기 소재가 사용될 수 없다. 다만, Suchanek등의 연구에 의하면 수열반응에 의하여 알루미나 제조시 실리카를 첨가하면서 종횡비가 매우 큰 판상형 입자가 얻어졌다. ${ }^{27)}$ 이에, salt 조건에서도 용융되지 않는 실리카를 capping agent로 선택하였으며, 판상형 알루미나 표면에 국부적으로 도포될 수 있도록 하 기 위하여 나노 크기의 입자를 사용하였다.

\section{2. 실험 방법}

모재용 판상 알루미나는 Merck사에서 판매되고 있는 $\alpha$ 상의 상용 알루미나 분말(RonaFilair ${ }^{\circledR}$ White Sapphire, $\geq 99.0 \%, 7.0-11.0 \mu \mathrm{m}, \mathrm{Merck} \mathrm{KGaA}$ )을 사용하였다. 돌 기 형성 source로 $\mathrm{Al}(\mathrm{OH})_{3}(63 \%$, Daejung Chemicals \& Metals Co., Ltd)를 $600^{\circ} \mathrm{C}$ 에서 하소하여 제조한 $\gamma$-상의 알 루미나를 사용하였다. Capping agent는 나노크기의 실리 카 분산용액(LUDOX ${ }^{\circledR} \mathrm{HS}-40,40 \mathrm{wt} \%$ suspension in $\mathrm{H}_{2} \mathrm{O}$, Sigma-Aldrich)을 사용하였으며, salt는 $\mathrm{NaCl}$ (Daejung Chemicals \& Metals Co., Ltd)과 $\mathrm{KCl}$ (99.5\%, Yakuri Pure Chemicals Co., Ltd)을 무게비 1 : 2로 혼합하여 사 용하였다.

$\alpha$-상의 판상형 알루미나 표면에 동종의 알루미나 돌기 를 형성하기 위하여 (1) 실리카 도포, (2) 열처리, 그리고
(3) 세척의 세 단계에 걸쳐 실험을 실시하였다. 첫번째 단 계인 실리카 도포 단계에서는 에탄올 $100 \mathrm{ml}$ 에 분산시킨 실리카 분산용액에 판상형 알루미나 입자 $10 \mathrm{~g}$ 을 첨가하 고 3 시간 동안 교반하며 용액내 균일하게 분산하였다. 교 반이 끝난 알루미나 분산 용액은 증류장치(evaporator)를 이용하여 용매를 제거하였다. 실리카 입자가 도포된 판상 알루미나 입자는 salt $30 \mathrm{~g}$ 과 $\gamma$-상의 알루미나 $2.5 \mathrm{~g}$ 을 순 차적으로 혼합한 후 $900-1100^{\circ} \mathrm{C}$ 에서 1 시간 동안 열처리 하였다. 열처리가 완료된 시료는 따뜻한 $1 \mathrm{M} \mathrm{-} \mathrm{HCl}$ 용액, $0.1 \mathrm{M}-\mathrm{HF}$ 용액과 증류수를 이용하여 세척한 후 $60^{\circ} \mathrm{C}$ 로 유지되는 오븐에서 10 시간 이상 건조하였다. 자세한 실험 조건은 Table 1에 나타내었다.

수득된 분말에 대해서는 X-선 회절분석기(P/MAX $2200 \mathrm{~V} /$ $\mathrm{PC}$, Rigaku Corp., $\mathrm{Cu}$ target $(\mathrm{K} \alpha=1.54 \AA))$ 를 이용하여 알루 미나 결정 형성 여부를 확인하였으며, FE-SEM (JSM-6700F, $\mathrm{JEOL}$ )를 이용하여 미세 구조를 관찰하였다. 그리고, TEM (TEM-4010, JEOL)을 사용하여 판상 알루미나와 표면에 형성된 동종돌기간의 계면을 관찰하였다.

\section{3. 결과 및 고찰}

\section{1. 원재료 분석}

알루미나 입자 표면에 돌기를 형성하기에 앞서 사용된 출발물질에 대한 분석을 실시하였다. Fig. 1은 모재로 사 용된 판상 알루미나 입자의 $\mathrm{SEM}$ 관찰결과로 형태가 일 정하지는 않으나 지름이 약 $10 \mu \mathrm{m}$ 이며 표면이 매끈한 판 상형 입자임을 확인하였다. 동종돌기의 source로 사용된 $\gamma$-상 알루미나는 $\mathrm{Al}(\mathrm{OH})_{3}$ 를 $600^{\circ} \mathrm{C}$ 에서 하소하여 제조하 였는데, 이때 하소단계에서 아래의 반응식과 같이 탈수 과정을 거쳐 알루미나가 형성된다. Fig. 2 에 $600^{\circ} \mathrm{C}$ 에서 하
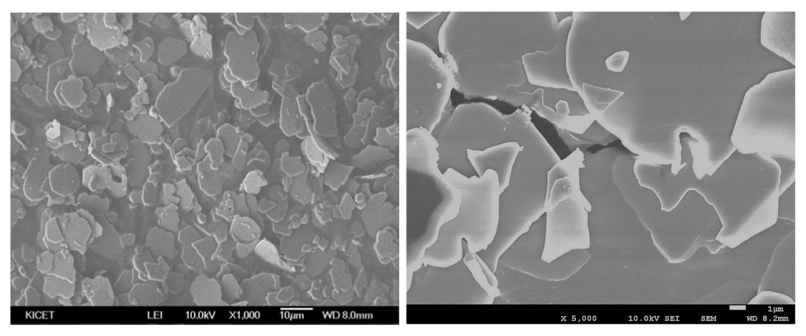

Fig. 1. SEM images of as purchased plate-like alumina particles. 


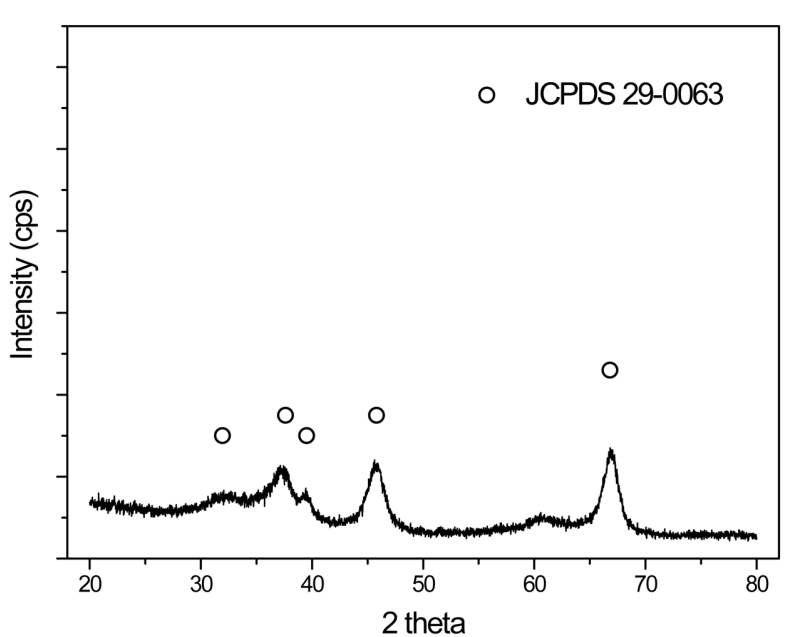

Fig. 2. XRD pattern of $\gamma$-alumina prepared by calcination of $\mathrm{Al}(\mathrm{OH})_{3}$.

소한 알루미나 분말에 대한 $\mathrm{X}$-선 회절분석 결과를 나타 내었다. 전반적으로 broad한 스펙트럼을 보여주고 있으나 $37.6^{\circ}, 45.8^{\circ}$ 및 $66.8^{\circ}$ 위치에서 뚜렷한 회절 피크가 관찰 되었는데, $\gamma$-상 알루미나의 (111), (200), (220) 면과 일치 하였다. 이로부터 나노크기의 $\gamma$-상 알루미나가 형성되었 음을 확인하였다. 본 연구에서는 나노크기의 $\gamma$-상 알루미 나를 돌기형성의 source로 사용하여 판상 알루미나 입자 표면에 2차 결정성장을 유도하였다.

$$
2 \mathrm{Al}(\mathrm{OH})_{3} \underset{\Delta}{\rightarrow} \mathrm{Al}_{2} \mathrm{O}_{3}+3 \mathrm{H}_{2} \mathrm{O}
$$

\section{2. 알루미나 돌기 형성}

$\alpha$-상의 판상 알루미나 표면에 돌기구조를 형성하기 위 해 돌기형성 source인 $\gamma$-상 알루미나와 capping agent로 실 리카 나노입자를 첨가한 후 molten-salt법을 이용하여 $900^{\circ} \mathrm{C}$ 에서 열처리하였다. Fig. 3 은 $\mathrm{BL} 1$ 조건으로 제조된 알루미나 분말에 대한 SEM 분석 결과이다. 전반적으로 판상 알루미나 입자의 크기와 형상에는 별다른 변화가 없 었다. 그러나, 개별 입자를 고배율로 확인하여 보면 표면 에 10-20 nm 크기의 작은 돌기들이 형성되었음을 확인 할 수 있는데, 이들 돌기는 알루미나 표면으로부터 돌출 되어 있으며 반구형으로 형성되었음을 확인하였다.

알루미나 입자 표면에 돌기의 형성 거동을 확인하고 capping agent의 효과를 알아보기 위해 capping agent 첨 가 없이 $\gamma$-상 알루미나만 첨가하여 molten-salt 합성을 진 행하였다. Fig. 4는 실리카를 첨가하지 않은 조건(BO)에 서 합성한 알루미나 입자에 대한 SEM 분석결과를 나타 내었는데, 전반적으로 판상 입자의 크기와 형태에는 별다 른 차이를 보이지 않았으며 부분적으로 알루미나 표면에 $100 \mathrm{~nm}$ 미만의 비정형 입자들이 관찰되었다(Fig. 4(b)). 이 러한 입자들은 Fig. 3에서 관찰된 돌기와는 크기나 형태

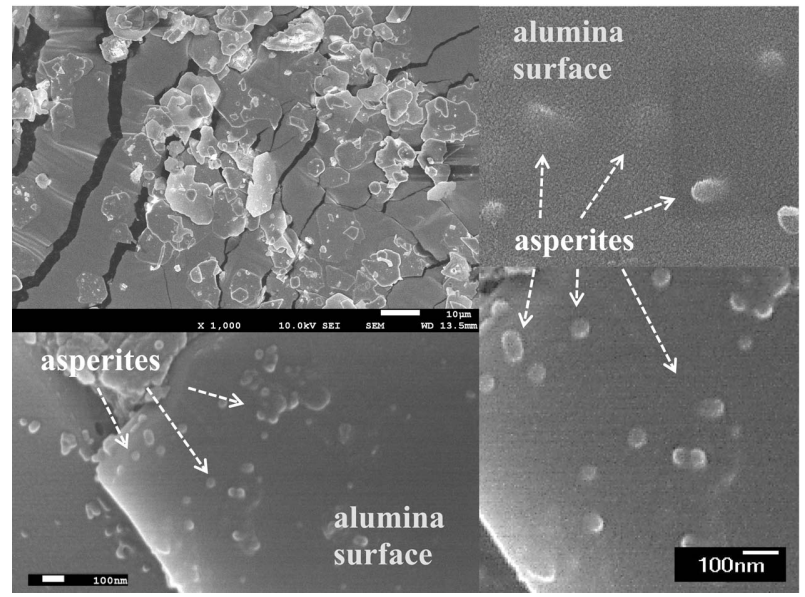

Fig. 3. SEM images of plate like alumina particles which were covered by capping agent before heat-treatment at $900{ }^{\circ} \mathrm{C}$ for the formation of asperites on the surface.

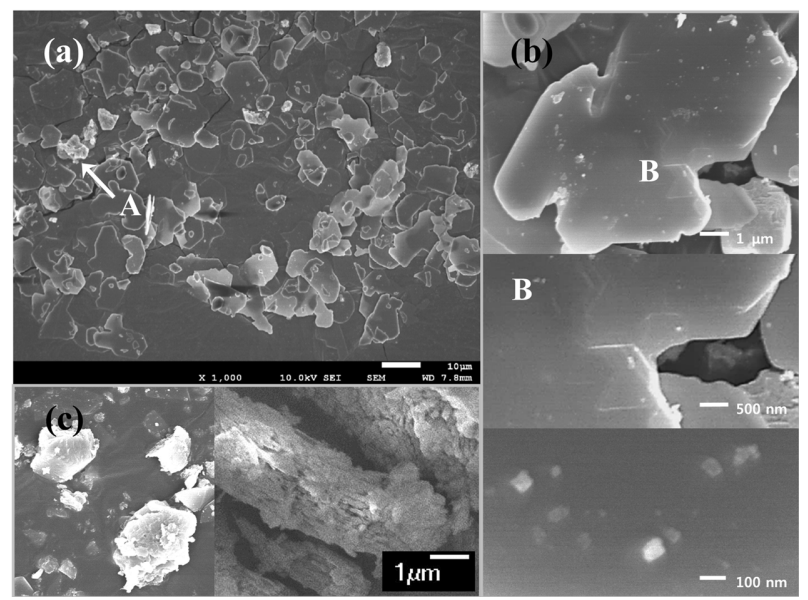

Fig. 4. SEM images of plate like alumina particles without capping agent coating before heat-treatment at $900^{\circ} \mathrm{C}$; (a) low magnification, (b) high magnification, and (c) agglomerates grown by $\gamma$-alumina itself.

에서 차이가 있었는데, 알루미나 표면에서 성장했다기 보 다 세척과정에서 제거되지 않은 salt 또는 미반응 $\gamma$-알루 미나인 것으로 추정된다. 오히려 알루미나의 표면을 확대 하여 보면 기존 입자에서는 확인되지 않았던 결정층이 관 찰되는데, (Fig. 4(b) C 영역) salt의 용융상태에서 $\gamma$-알루 미나는 source로 작용하여 판상형 알루미나의 표면에서 균 일한 층으로 결정이 성장한 것으로 추정된다. 그 외에도 $10 \mu \mathrm{m}$ 크기의 응집된 비정형 입자가 존재하는데(Fig. 4(b) B 영역), 이의 확대된 이미지(Fig. 4(c))에 따르면 다층형 판상입자인 것으로 확인 되었다. 기존 연구결과에 따르면, molten-salt 분위기에서 $\gamma$ 상-알루미나 입자 자체 seed로 작 용할 수 있으며 그 결과 층상형의 알루미나 클러스터를 형성하게 된다. ${ }^{26)}$ 따라서 $\mathrm{BO}$ 조건에서 확인된 응집입자 는 판상형 알루미나 입자 표면 외에 $\gamma$ 상-알루미나 입자의 
부가반응으로 생성된 클러스터 입자인 것으로 예상된다.

이러한 결과들은 capping agent의 도포여부에 따라 입 자표면 동종돌기 형성이 크게 영향을 받는 것을 보여주 고 있다. 그러므로, 합성 과정에서 실리카 나노분말의 도 포상태를 확인하기 위하여 판상형 알루미나와 실리카 분 말만을 혼합한 후 건조과정을 거쳐 $900^{\circ} \mathrm{C}$ 에서 열처리한 분말에 대해 $\mathrm{SEM}$ 이미지를 관찰하였다. 실험에 사용된 실리카 입자는 비정질 상의 나노분말로 $\mathrm{SEM}$ 측정이 어 려울 수 있다고 예상되었으며, 실리카 분말의 도포상태를 보다 뚜렷하게 관찰하기 위하여 Table 1에 나타낸 바와 같이 실리카 분말을 과량 첨가한 후( $\mathrm{LU}$ 조건) $900^{\circ} \mathrm{C}$ 에서 열처리 하였다. Fig. 5(a)는 LU 시료에 대한 SEM 분석결 과로 알루미나 입자 표면에서 실리카 입자가 두껍게 도 포되어 있는 것을 관찰할 수 있었다. Fig. 5(b)는 실리카 가 도포된 알루미나 입자를 salt 조건에서 열처리 한 결 과인데, 이 이미지에서도 역시 알루미나 표면에 입자상태 로 도포된 실리카를 확인할 수 있다. 따라서, 나노 입자 인 실리카의 첨가량에 따라 판상 알루미나 표면의 노출 면적이 조절가능 하며, 즉 capping agent의 도포상태에 따 라 돌기의 핵생성 사이트를 조절할 수 있으므로 노출된 알루미나 표면으로부터 선택적으로 2차 결정 성장이 가 능함을 알 수 있었다.

Fig. 6은 molten-salt 환경에서 판상형 알루미나 입자의 열처리 과정 중 실리카 capping agent의 도포에 따른 알 루미나 입자 표면 결정성 돌기 형성 과정을 모식도로 나 타내었다. 실리카는 도포단계에서 첨가량 및 혼합 등 공 정조건에 따라 알루미나 표면의 노출 정도를 결정하게 된 다. 이렇게 표면이 도포된 알루미나는 열처리 과정에서 노출된 표면이 동종의 나노돌기 형성 사이트로 작용하여 2차 결정 성장이 일어나게 되어 돌기를 형성 시킨다.

$\mathrm{BL1}$ 조건으로 제조된 동종돌기 형성 알루미나 입자에 대한 특성을 분석하기 위하여 $\mathrm{X}$-선 회절 분석을 실시하 였으며 그 결과를 Fig. 7에 나타내었다. 반응전 판상 입 자의 결정상은 $\alpha$-상으로만 존재하는데, 반응 후 회절 패 턴에서는 $42.7^{\circ}$ 및 $48.5^{\circ}, 64.6^{\circ}, 67.5^{\circ}$ 위치에서 새로운 피 크가 나타났으며, $\theta$-상 알루미나의 회절 패턴과 일치하였 다. 알루미나의 결정상은 반응 온도에 따라 아래와 같이 $\eta$ - 또는 $\gamma$-상이 $\theta$-상을 거쳐 $\alpha$-상으로 전이 한다.

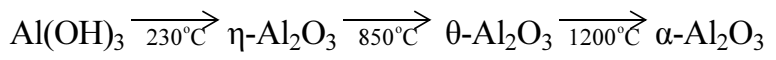

본 연구에서는 $\mathrm{Al}(\mathrm{OH})_{3}$ 이 $600^{\circ} \mathrm{C}$ 하소하여 얻어진 $\gamma$-상 의 알루미나를 반응 source로 하여 $900^{\circ} \mathrm{C}$ 에서 반응을 진 행하였다. 이 때, 반응 온도 $900^{\circ} \mathrm{C}$ 는 판상 알루미나 표면 에 돌기모양의 2 차 결정상이 성장하는데는 적합하였으나 형성된 돌기의 결정상은 $\theta$-상이었으므로 열처리 온도를 $1200^{\circ} \mathrm{C}$ 까지 상승한다면 모재와 같은 $\alpha$-상으로 전이 될 것 으로 예상된다.

$\theta$-상 알루미나로 확인된 돌기 입자가 판상 알루미나 표 면으로부터 성장하였는지 그 여부를 확인하기 위하여 알루

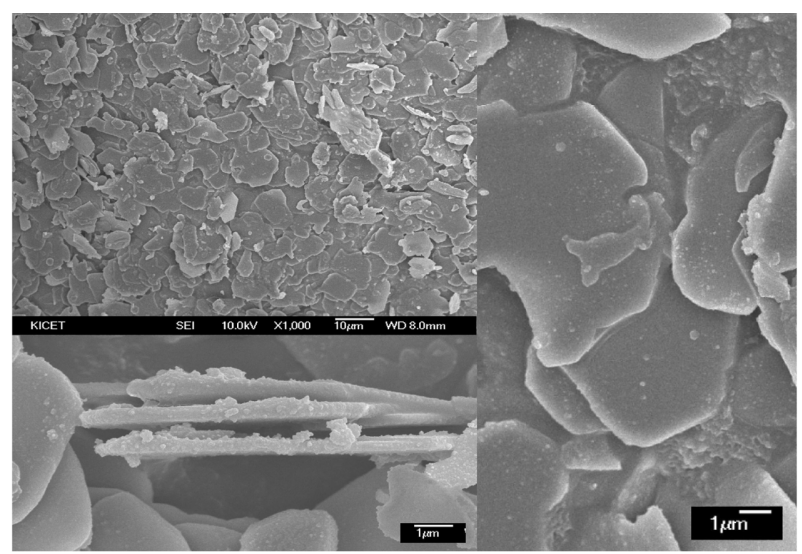

(a)

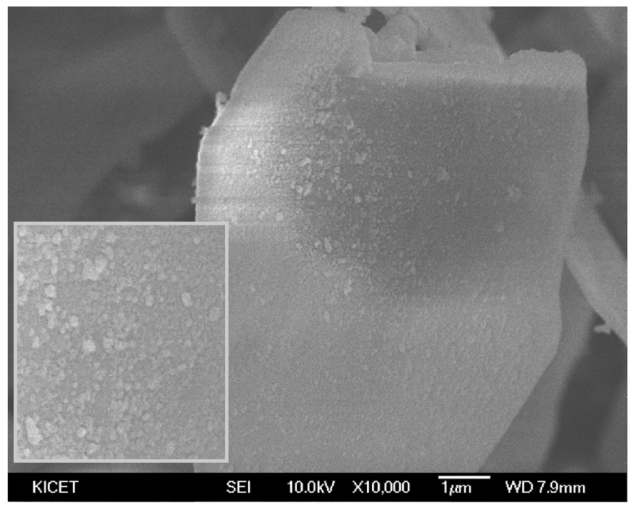

(b)

Fig. 5. SEM images of plate like alumina particles (a) just after mixing the capping agent only and (b) heattreated at $900^{\circ} \mathrm{C}$.

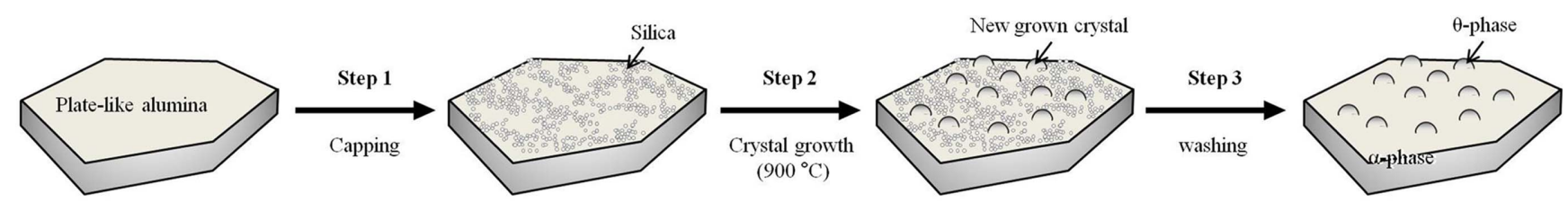

Fig. 6. Schematic model of the formation mechanism of nano-asperites on the surface of plate like alumina particle by using capping agent. 
미나 모재와 돌기 사이의 계면을 TEM 분석을 실시하였 다. Fig. 8은 돌기가 형성된 판상 입자의 단면에 대한 고분 해능 TEM 이미지를 보여주고 있다. 어두운 색으로 나타난 고결정상 영역은 모재에 해당되는 판상형 알루미나로 입자

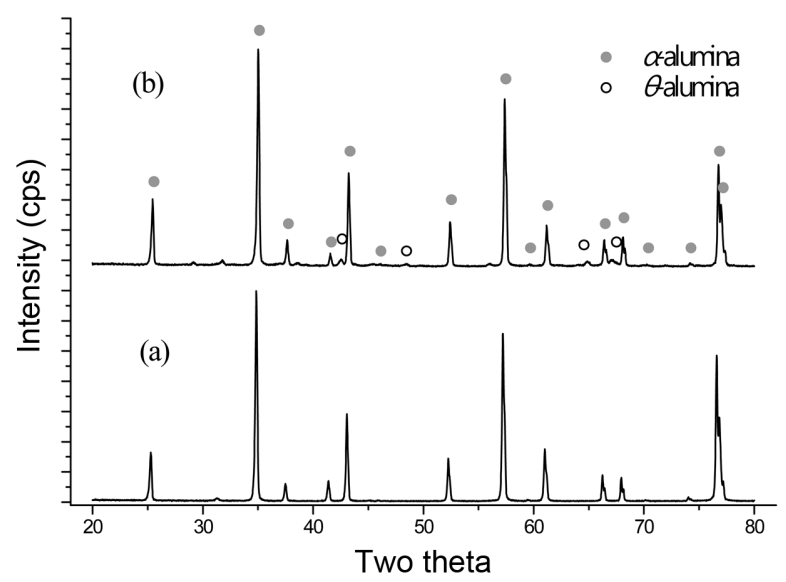

Fig. 7. XRD patterns of (a) as purchased plate-like alumina and (b) the alumina which formed the asperities after heat treated at $900^{\circ} \mathrm{C}$.
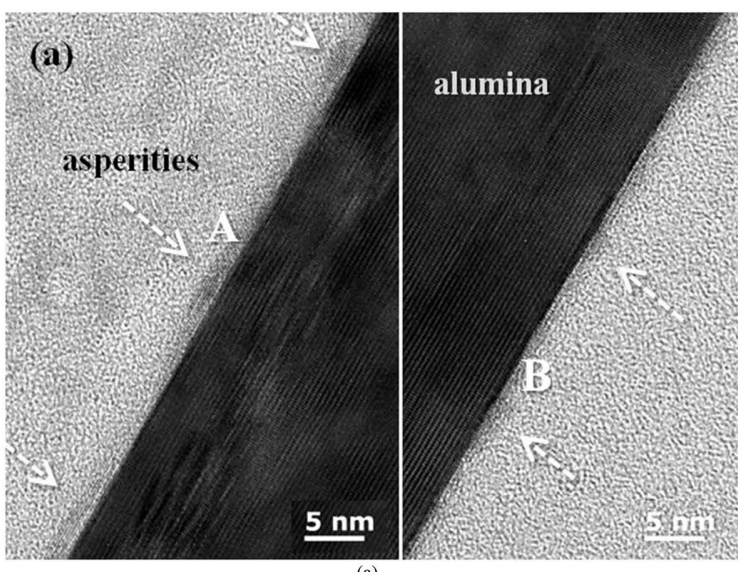

(b)
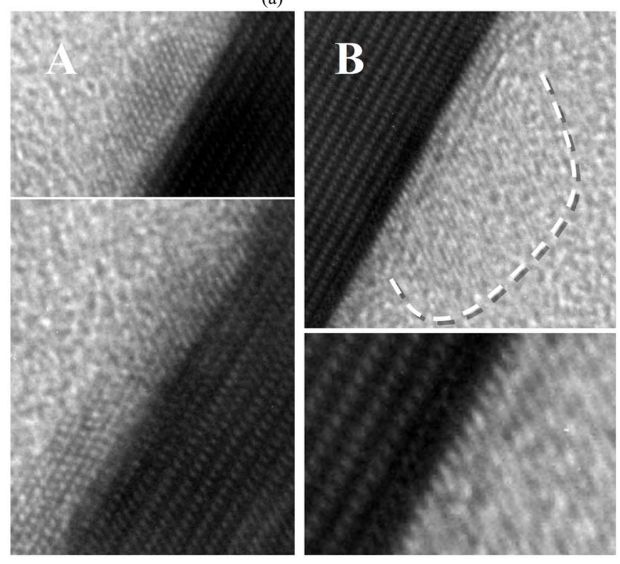

Fig. 8. High resolution TEM images of the cross-section of plate like alumina particle ((b) shows high magnification image of (a)).
의 양쪽 표면을 각각 $\mathrm{A}$ 와 $\mathrm{B}$ 로 나타내었다(Fig. 8(a)). 알루 미나 입자의 표면은 매우 평평하였으며 부분적으로 수 나 노 크기의 돌기들이 관찰되었다. 판상 알루미나 입자와 표면에 형성된 돌기 사이에 형성된 계면을 보다 자세히 관찰 시 돌기는 입자 표면에서 결정형으로 안정적으로 성 장한 것으로 보이며 계면 역시 모재와 미스매치가 거의 없다고 판단되었다

\section{4. 결 론}

본 연구에서는 $\gamma$-상의 알루미나를 반응 source로 사용 하여 판상 알루미나 표면에 동종의 결정성 돌기를 형성 하고자 하였으며 이때 capping agent를 첨가하여 돌기 형 성 사이트를 조절하였다. 나노 크기의 실리카 입자를 capping agent로 알루미나 표면에 도포시 첨가량에 따라 알루미나 표면의 노출정도가 결정되었고 노출 표면에 선택적으로 동종의 돌기가 형성되었다. 또한, TEM 분석을 통해 생성 된 결정상의 나노돌기는 $\theta$-상의 알루미나임을 확인하였다.

\section{Acknowledgment}

이 논문은 교육과학기술부의 융합파이오니아 사업 (No. NRF 2010-0019468)의 지원을 받아 수행되었으며, 연구비 지원에 감사드립니다.

\section{REFERENCES}

1. B. Bhushan, "Biomimetics Inspired Surfaces for Drag Reduction and Oleophobicity/Philicity," Beilstein J. Nanotechnol., 2 [1] 66-84 (2011).

2. B. Bhushan, "Biomimetics: Lessons from Nature-An Overview," Philos. Trans. R. Soc., A, 367 [1893] 1445-86 (2009).

3. Q. Chen and N. M. Pugno, "Bio-mimetic Mechanisms of Natural Hierarchical Materials: A Review," J. Mech. Behav. Biomed. Mater., 19 3-33 (2013).

4. I. Corni, T. J. Harvey, J. A. Wharton, K. R. Stokes, F. C. Walsh, and R. J. K. Wood, "A Review of Experimental Techniques to Produce a Nacre-like Structure," Bioinspiration Biomimetics, 7 [3] 031001 (2012).

5. F. Barthelat, H. Tang, P. D. Zavattieri, C. M. Li, and H. D. Espinosa, "On the Mechanics of Mother-of-pearl: A Key Feature in the Material Hierarchical Structure," J. Mech. Phys. Solids, 55 [2] 306-37 (2007).

6. H. Kakisawa and T. Sumitomo, "The Toughening Mechanism of Nacre and Structural Materials Inspired by Nacre," Sci. Technol. Adv. Mater., 12 [6] 064710 (2011).

7. F. Barthelat, C. M. Li, C. Comi, and H. D. Espinosa, "Mechanical Properties of Nacre Constituents and Their Impact on Mechanical Performance," J. Mater. Res., 21 [8] 1977-86 (2006).

8. R. Wang and H. S. Gupta, "Deformation and Fracture 
Mechanisms of Bone and Nacre," Annu. Rev. Mater. Res., 41 41-73 (2011).

9. R. Z. Wang, Z. Suo, A. G. Evans, N. Yao, and I. A. Aksay, "Deformation Mechanisms in Nacre," J. Mater. Res., 16 [09] 2485-93 (2001).

10. P. Somasundran, B. Markovic, S. Krishnakumar, and X. Yu, pp. 127-92, Ed. by K. S. Birdi, Handbook of Surface and Colloid Chemistry, CRC Press, Boca Raton, FL, 1997.

11. F. J. Maile, G. Pfaff, and P. Reynders, "Effect Pigments Past, Present and Future," Prog. Org. Coat., 54 [3] 150-63 (2005).

12. R. A. Eppler, "Selecting Ceramic Pigments," Proc., Annu. Meet. Jt. Fall Meet. - Am. Ceram. Soc., Mater. Equip. Whitewares Div., 8 [11/12] 1139-49 (2008).

13. L. J. Bonderer, K. Feldman, and L. J. Gauckler, "Plateletreinforced Polymer Matrix Composites by Combined Gelcasting and Hot-pressing. Part I: Polypropylene Matrix Composites," Compos. Sci. Technol., 70 [13] 1958-65 (2010).

14. O. Ekiz, A. F. Dericioglu, and H. Kakisawa, "An Efficient Hybrid Conventional Method to Fabricate Nacre-like Bulk Nano-laminar Composites," Mater. Sci. Eng., C, 29 [6] 2050-54 (2009).

15. S. N. Gurbuz and A. F. Dericioglu, "Effect of Reinforcement Surface Functionalization on the Mechanical Properties of Nacre-like Bulk Lamellar Composites Processed by a Hybrid Conventional Method," Mater. Sci. Eng., C, 33 [4] 2011-19 (2013).

16. N. E. Bell, S. B. Cho, and J. H. Adair, "Size and Shape Control of $\alpha$-Alumina Particles Synthesized in 1,4-Butanediol Solution by $\alpha$-Alumina and $\alpha$-Hematite Seeding," $J$. Am. Ceram. Soc., 81 [6] 1411-20 (1998).

17. S. F. Chen, S. H. Yu, T. X. Wang, J. Jiang, H. Cölfen, B. Hu, and B. Yu, "Polymer-Directed Formation of Unusual $\mathrm{CaCO}_{3}$ Pancakes with Controlled Surface Structures," Adv. Mater., 17 [12] 1461-65 (2005).

18. S. P. Garcia and S. Semancik, "Controlling the Morphology of Zinc Oxide Nanorods Crystallized from Aqueous Solutions: The Effect of Crystal Growth Modifiers on Aspect Ratio," Chem. Mater., 19 [16] 4016-22 (2007).

19. S. -H. Yu and H. Cölfen, "Bio-inspired Crystal Morphogenesis by Hydrophilic Polymers," J. Mater. Chem., 14 [14] 2124-47 (2004).

20. N. J. Nicholas, G. V. Franks, and W. A. Ducker, "Selective Adsorption to Particular Crystal Faces of ZnO," Langmuir, 28 [18] 7189-96 (2012).

21. M. N. Danchevskaya, Y. D. Ivakin, S. N. Torbin, and G. P. Muravieva, "The Role of Water Fluid in the Formation of Fine-Crystalline Oxide Structure," J. Supercrit. Fluids, 42 [3] 419-24 (2007).

22. W. J. Li, E. W. Shi, and Z. W. Yin, "Growth Habit of Rutile and $\alpha-\mathrm{Al}_{2} \mathrm{O}_{3}$ Crystals," J. Cryst. Growth, 208 [1] 546-54 (2000).

23. S. G. Lee, H. C. Park, B. S. Kang, G. S. Seo, S. S. Hong, and S. S. Park, "Synthesis of $\alpha$-alumina Platelets from $\gamma$-alumina with and without Microwaves," Mater. Sci. Eng., A, 466 [1] 7983 (2007).

24. L. -H. Zhu, Q. -W. Huang, and W. Liu, "Synthesis of Platelike $\alpha-\mathrm{Al}_{2} \mathrm{O}_{3}$ Single-crystal Particles in $\mathrm{NaCl}-\mathrm{KCl}$ Flux Using $\mathrm{Al}(\mathrm{OH})_{3}$ Powders and Starting Materials," Ceram. Int., 34 [7] 1729-33 (2008).

25. S. Hashimoto, S. Zhang, W. E. Lee, and A. Yamaguchi, "Synthesis of Magnesium Aluminate Spinel Platelets from $\alpha$-Alumina Platelet and Magnesium Sulfate Precursors," $J$. Am. Ceram. Soc., 86 [11] 1959-61 (2003).

26. B. Y. Kim, Y. J. Lee, D. Shin, S. R. Kim, W. T. Kwon, and Y. Kim, "Effect of Salt on Crystal Growth of Plate-like Alumina Particles by Molten-salt Method," Korean Chem. Eng. Res. - Submitted.

27. W. L. Suchanek, J. M. Garces, P. F. Fulvio, and M. Jaroniec, "Hydrothermal Synthesis and Surface Characteristics of Novel Alpha Alumina Nanosheets with Controlled Chemical Composition," Chem. Mater., 22 [24] 6564-74 (2010). 